\title{
The interaction between surface water and groundwater and its effect on water quality in the Second Songhua River basin, northeast China
}

\author{
Bing Zhang ${ }^{1,2}$, Xianfang Song ${ }^{2, *}$, Yinghua Zhang ${ }^{2}$, Ying MA ${ }^{2}$, \\ Changyuan TAng ${ }^{3}$, Linu YAng ${ }^{2}$ and Zhong-Liang WAng ${ }^{1}$ \\ ${ }^{1}$ Tianjin Key Laboratory of Water Resources and Environment, Tianjin Normal University, \\ 300387, Tianjin, China. \\ ${ }^{2}$ Key Laboratory of Water Cycle and Related Land Surface Processes, Institute of Geographic Sciences \\ and Natural Resources Research, Chinese Academy of Sciences, 100101, Beijing, China. \\ ${ }^{3}$ Departments of Environmental Science $\mathcal{E}$ Landscape Architecture, Faculty of Horticulture, Chiba University, \\ 271-8510 Chiba, Japan. \\ *Corresponding author.e-mail: songxf@igsnrr.ac.cn
}

The relationship between surface water and groundwater not only influences the water quantity, but also affects the water quality. The stable isotopes $\left(\delta \mathrm{D}, \delta^{18} \mathrm{O}\right)$ and hydrochemical compositions in water samples were analysed in the Second Songhua River basin. The deep groundwater is mainly recharged from shallow groundwater in the middle and upper reaches. The shallow groundwater is discharged to rivers in the downstream. The runoff from upper reaches mainly contributed the river flow in the downstream. The CCME WQI indicated that the quality of surface water and groundwater was 'Fair'. The mixing process between surface water and groundwater was simulated by the PHREEQC code with the results from the stable isotopes. The interaction between surface water and groundwater influences the composition of ions in the mixing water, and further affects the water quality with other factors.

\section{Introduction}

Surface water and groundwater are the key resources for sustainable development of society and environment. The interaction between surface water and groundwater is one of the processes of hydrologic cycle. Furthermore, groundwater and surface water interacts throughout all landscapes (Winter et al. 1998). The relationship between surface water and groundwater interactions is commonly investigated at the river reach scale, and is generally classified as connected or disconnected type systems (Banks et al. 2011). The stable isotopes $\left(\delta \mathrm{D}, \delta^{18} \mathrm{O}\right)$ and hydrochemistry are widely applied to study the interaction between surface water and groundwater (Ayenew et al. 2008; Baskaran et al. 2009; Banks et al. 2011; Mori et al. 2015). The stable isotopes and hydrochemical composition move with water in the hydrological cycle. Consequently, the isotopic composition of water and hydrochemical techniques can be used to characterise the fingerprint of water movement. The case studies on the relationship between surface water and groundwater are well documented in the literature (Promma et al. 2006; Krause et al. 2007; Brunner et al. 2011).

When groundwater mixes with surface water, they impart their characteristics upon one another, and unique gradients develop for each parameter (Gardner 1999). The interaction between surface

Keywords. Surface water; groundwater; stable isotopes; water quality; Second Songhua River basin. 
water and groundwater affects the hydrochemical composition of water bodies, and influences the water quality further. To understand the impact of the interaction between surface water and groundwater on the hydrochemical composition, the PHREEQC code was undertaken to quantitatively simulate the geochemical mixing process of surface water and groundwater (Thyne et al. 2004; Parkhurst and Appelo 2013). The water quality index (WQI) transforms water quality parameter levels to an integrated indicator value, and describes the general situation of water bodies (Melloul and Collin 1998; Štambuk-Giljanović 1999; Cude 2001). The WQI performed by the Canadian Council of Ministers of the Environment (CCME) is an efficient water quality index, providing a general and readily understood description of water (Lumb et al. 2006; Akkoyunlu and Akiner 2012).

The whole length of the Second Songhua River is approximately $958 \mathrm{~km}$, with an annual mean river flow of $14.8 \mathrm{~km}^{3}$ (figure 1). The Second Songhua River and Nen River meet near Songyuan city to form the Songhua River (Lin et al. 2008). The Second Songhua River is the main drinking water source for Jilin and Changchun cities. Thus, the water quality is very important to society and humans. The majority of water quality studies are of heavy metal, toxic organic pollutants and other water quality indices ( $\mathrm{Liu}$ and $\mathrm{Yu}$ 1999; $\mathrm{Yu}$ et al. 2003; Lin et al. 2008; Sun et al. 2014). However, the mixing processes between surface water and groundwater, and water quality influenced by the interaction are little studied (Bai et al. 2011).

The surface water and groundwater are significant to ecosystem and society in the Second Songhua River basin. Furthermore, mixing of surface water and groundwater is the base to understand the water evolution and water quality. The purposes of this study are to: (1) quantitatively interpret the relationship between surface water and the groundwater by hydrogen and oxygen stable isotopes; (2) simulate the hydrochemical composition and discuss the mixing processes of the surface water and groundwater; and (3) assess the water quality of surface water and groundwater.

\section{Study area}

\subsection{Study site description}

The Second Songhua River basin (124 $36^{\prime}-$ $128^{\circ} 50^{\prime} \mathrm{E}, 41^{\circ} 44^{\prime}-45^{\circ} 24^{\prime} \mathrm{N}$ ) is located in the Jilin province, northeast China (figure 2). The total area of the Second Songhua River watershed is $7.34 \times$ $10^{4} \mathrm{~km}^{2}$. The mean annual precipitation is about $562 \mathrm{~mm}$, and $60 \%$ of the precipitation occurs during June-August (Bai et al. 2011).

The dark brown soil and white pulp soil distribute in the upper reaches. The meadow soil, swamp soil and alluvial soil distribute in the mountain valley. The black soil, white pulp soil and meadow soil occur in the middle reaches of the Second Songhua River. The soil distributions in the downstream are chernozem, meadow soil, sand soil, alluvial soil and alkaline soil (figure 3a). The primeval forest and natural secondary forest are located in the upper reaches, with the forest coverage rate more than $70 \% .40 \%$ of area in the middle reaches is forest, the rest is farmland. More than $90 \%$ area in the downstream is farmland, the main forest is poplar planted to prevent desertification by the wind (figure $3 \mathrm{~b}$ ).

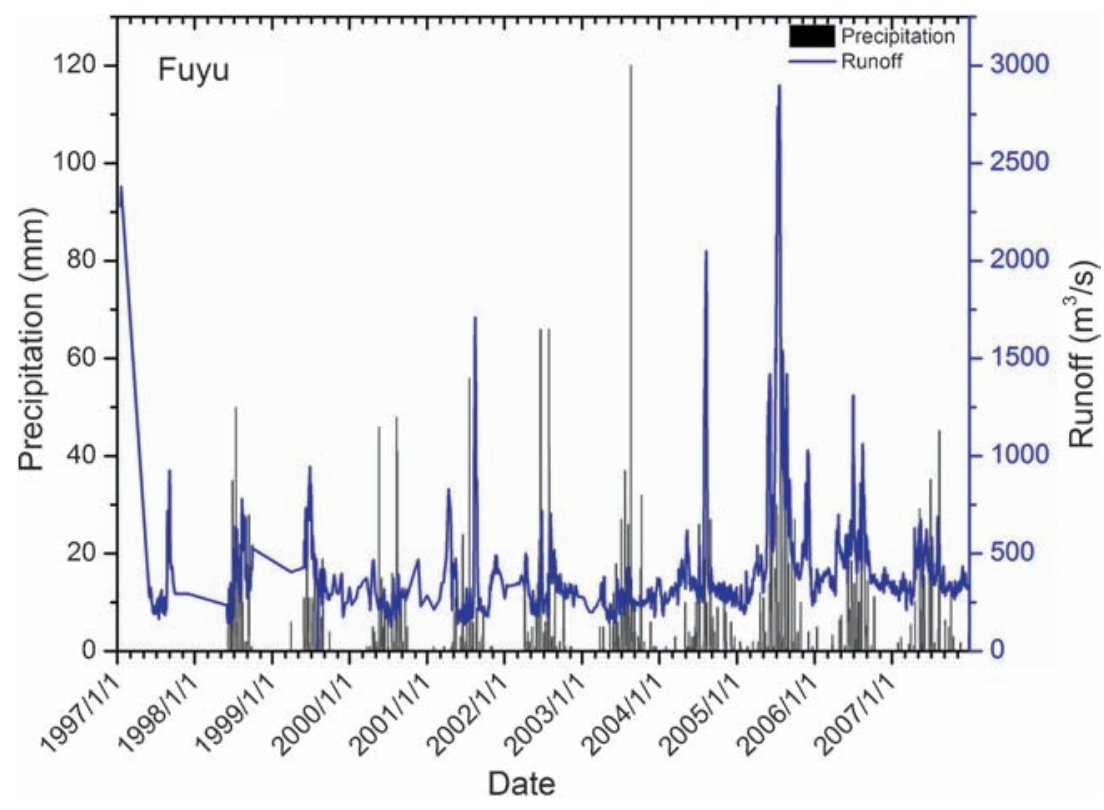

Figure 1. The daily precipitation and river flow at the Fuyu hydrometric station. 

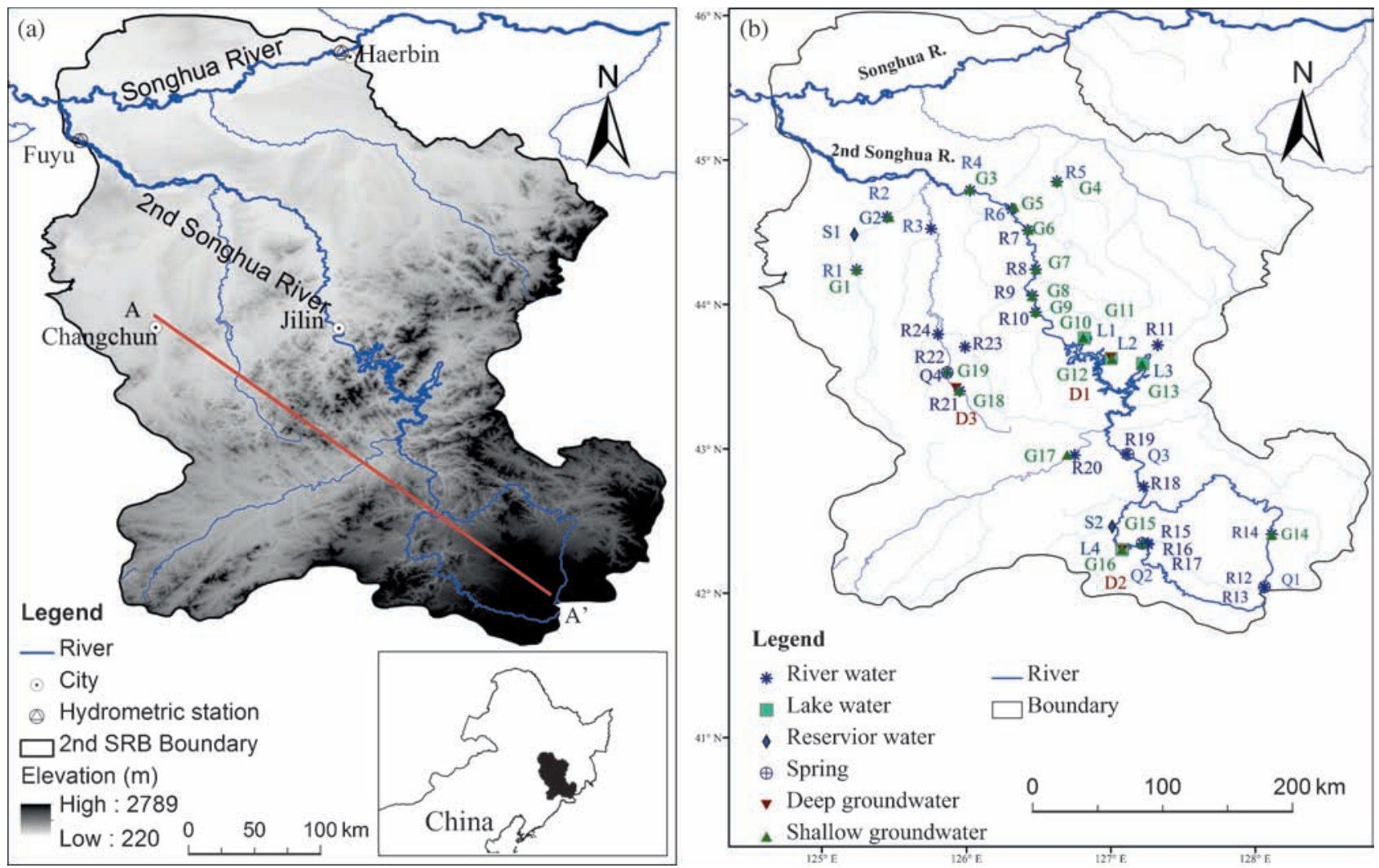

Figure 2. (a) Location and (b) water samples in the $2^{\text {nd }}$ Songhua River basin.
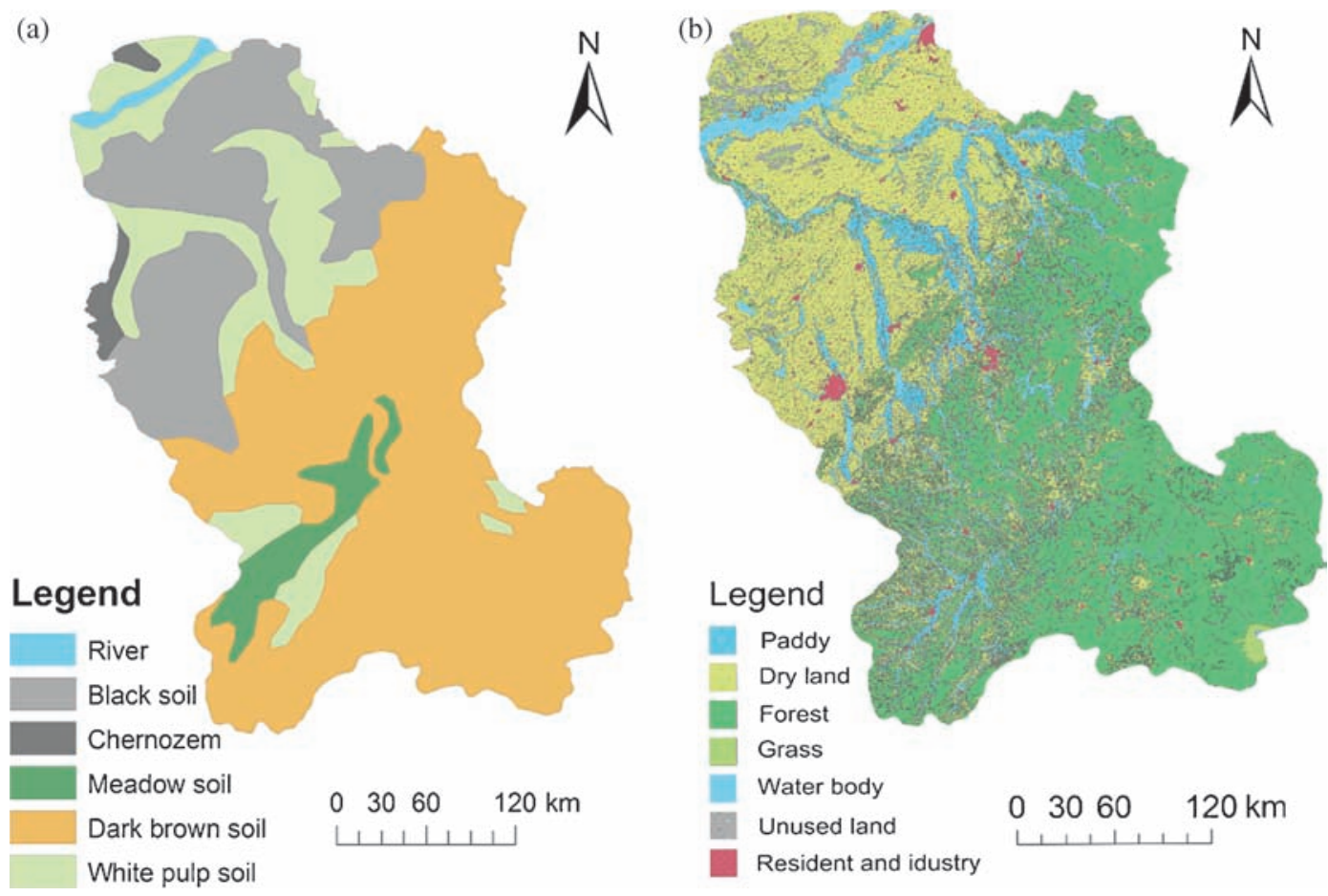

Figure 3. (a) Distribution of soil and (b) landuse in the $2^{\text {nd }}$ Songhua River basin.

\subsection{Hydrogeology}

The elevation above sea level increases from northwest to southeast in the Second Songhua River

basin. The altitude of most area ranges from 300 to $800 \mathrm{~m}$. The Baiyun Peak (altitude $2691 \mathrm{~m}$ ) is the highest mountain in the Changbai Mountains. The geological landforms are mountain areas, trough 
fault basins, diluvial plains, and alluvial plains from upper reaches to downstream, respectively. The aquifer of the river valley contains two layers. The first layer is sandy loam and clay, and the second layer is sand gravel. However, the unified aquifer in the alluvial plain consists of Holocene accumulation and the fine sand of Pleistocene series (Bai et al. 2011). The upper layer of the geology is loesses, and the bedrock is mudstone in the plain area near Changchun city. The upper layer is basalt and mudstone, and the bedrock is granite and gneiss in the middle and upper reaches, respectively (Institute of Hydrogeology and Environmental Geology 1979) (figure 4).

\section{Methods}

\subsection{Water sampling}

Surface water and groundwater were sampled along the Second Songhua River during June 6-12, 2011 (figure 2). Surface water was collected from rivers, lakes, and reservoirs. The shallow and deep groundwater samples were collected from shallow (sampling depth $<60 \mathrm{~m}$ ) and deep (sampling depth $\geq 60 \mathrm{~m}$ ) wells, respectively. Electrical conductivity (EC), $\mathrm{pH}$ and water temperature were measured in situ via an $\mathrm{EC} / \mathrm{pH}$ meter (WM22EP, Toadkk, Japan), which was previously calibrated. One $100 \mathrm{~mL}$ polyethylene bottle with watertight cap was used to store filtered $(0.45 \mu \mathrm{m}$ Millipore membrane filter) water for the analysis of hydrogen and oxygen stable isotopes. Two $50 \mathrm{~mL}$ polyethylene bottles with watertight caps were used to store filtered water for the determination of cations and anions. One bottle was acidified with $\mathrm{HNO}_{3}$ to $\mathrm{pH} \sim 2$ for cation determination. The other bottle for anion analysis was kept unacidified. All samples were stored at $4^{\circ} \mathrm{C}$ after bottling. The water samples were analyzed within a week in the laboratory.

\subsection{Analytical methods}

\subsubsection{Stable isotope analysis}

The stable hydrogen and oxygen isotopes in surface water and groundwater were analysed in the Key Laboratory of Water Cycle and Related Land Surface Processes of the Institute of Geographic Sciences and Natural Resources Research (IGSNRR), Chinese Academy of Sciences (CAS). The laser spectroscopic analysis of liquid water samples (DLT-100, Los Gatos Research Inc., USA) was used to analyse the isotopic composition. The results are expressed conventionally as $\delta$-values, representing deviation in per mil (\%o) from the isotopic composition of a specified standard (Vienna Standard Mean Ocean Water, VSMOW),

$$
\delta^{18} \mathrm{O}(\delta \mathrm{D})=1000 \times\left[\left(R_{\text {sample }} / R_{\text {standard }}\right)-1\right]
$$

where $R$ refers to ${ }^{2} \mathrm{H} /{ }^{1} \mathrm{H}$ or ${ }^{18} \mathrm{O} /{ }^{16} \mathrm{O}$ ratios in both sample and standard. The measurement accuracy was consistently $\pm 1 \%$ for $\delta \mathrm{D}$ and $\pm 0.2 \%$ for $\delta^{18} \mathrm{O}$, respectively.

\subsubsection{Hydrochemistry of surface and groundwater}

The major ions of water samples were treated and analyzed in the physical and chemical analysis center laboratory of the Institute of Geographic Sciences and Natural Resources Research (IGSNRR), Chinese Academy of Sciences (CAS). Cations $\left(\mathrm{Na}^{+}, \mathrm{K}^{+}, \mathrm{Ca}^{2+}, \mathrm{Mg}^{2+}\right)$ in the water samples were measured by inductively coupled plasma optical emission spectrometry (ICP-OES) (Perkin-Elmer Optima 5300 DV, USA). The concentrations of aluminium $(\mathrm{Al})$, cadmium $(\mathrm{Cd})$, copper $(\mathrm{Cu})$, iron $(\mathrm{Fe})$, manganese $(\mathrm{Mn})$, lead $(\mathrm{Pb})$, selenium $(\mathrm{Se})$ and zinc $(\mathrm{Zn})$ were determined by ICP-OES. Major anions $\left(\mathrm{Cl}^{-}, \mathrm{NO}_{3}^{-}, \mathrm{SO}_{4}^{2-}\right)$ were carried out on ion chromatography (IC) (Shimadzu LC-10ADvp, Japan). The $\mathrm{HCO}_{3}^{-}$concentration was determined

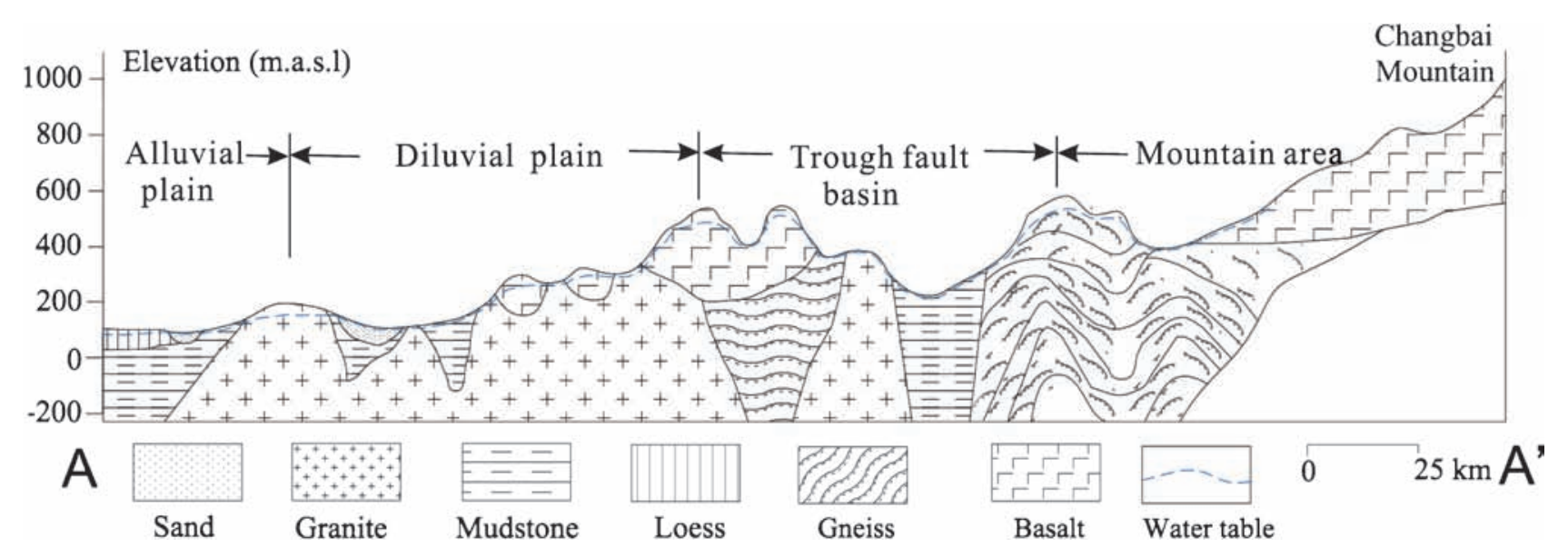

Figure 4. The schematic hydrogeology of cross section $\mathrm{A}-\mathrm{A}^{\prime}$. 
by titration with $0.02 \mathrm{~N}$ sulfuric acid on the day of sampling before filtration; methyl orange endpoint titration was used with the final $\mathrm{pH}$ being 4.2-4.4. The limits of detection of ICP-OES and IC are $1 \mu \mathrm{g} / \mathrm{L}$ and $1 \mathrm{mg} / \mathrm{L}$, respectively. Analytical precision for major ions was within $1 \%$. For all water samples, ion balance errors (IBE) were $<10 \%$, and most of them were $<5 \%$. The total dissolved solid (TDS) was calculated by the concentrations of major ions in water (AquaChem Schlumberger Water Services).

\subsection{Geochemical modelling}

PHREEQC for Windows (PHREEQC Interactive version 3.0, U.S. Geological Survey) is a computer program for simulating chemical reactions and transport processes in natural or polluted water, in laboratory experiments, or in industrial processes (Parkhurst and Appelo 2013). PHREEQE was capable of simulating a variety of geochemical reactions for a system, including mixing of waters, effects of changing temperature, etc. In mixing, each solution is multiplied by its mixing fraction and a new solution is calculated by summing over all of the fractional solutions. The mix data block is used to investigate the hydrochemical composition impacted by the interaction between surface water and groundwater. The mixing fraction is the contribution percentage of surface water and groundwater to the mixture, which is calculated by the stable isotopes and hydrochemical tracers.

The accuracy of a simulation is evaluated by comparing the simulated values to measurements. The relative error (re) and the standard deviation of the error $(s d e)$ are used to measure the difference between simulated results and measured values of the major ions in water (Lange 2005).

$$
\begin{array}{r}
e=y_{m}-y_{c} \\
r e=\frac{y_{m}-y_{c}}{y_{m}} \\
s d e=\sigma(e)
\end{array}
$$

where $y_{m}$ indicates the measured concentration of the ion; $y_{c}$ is the calculated value of the ion concentration; $e$ is one of the ions; $\sigma$ is the standard deviation.

\subsection{Water quality index}

The CCME WQI is a useful and efficient index to assess water quality relative to its desirable state. The index is based on a combination of three factors:

(1) The number of variables whose objectives are not met (scope):

$$
F 1=\left(\frac{\text { Number of failed variables }}{\text { Total number of variables }}\right) \times 100
$$

(2) The frequency with which the objectives are not met (frequency):

$$
F 2=\left(\frac{\text { Number of failed tests }}{\text { Total number of tests }}\right) \times 100
$$

(3) The amount by which the objectives are not met (amplitude). These are combined to produce a single value (between 0 and 100) that describes water quality (CCME 2001; GEMS 2007). When the test value must not exceed the objective, the excursion is expressed as follows:

$$
\text { excursion }_{i}=\left(\frac{\text { FailedTestValue }_{i}}{\text { Objective }_{i}}\right)-1
$$

The normalised sum of excursions, or nse, is calculated as:

$$
n s e=\left(\frac{\sum_{i=1}^{n} \text { excursion }_{i}}{\# \text { of tests }}\right)
$$

Then, $F 3$ is calculated as the equation:

$$
F 3=\left(\frac{n s e}{0.01 n s e+0.01}\right)
$$

The calculation of CCME WQI is as follows:

$$
\text { CCMEWQI }=100-\left(\frac{\sqrt{F 1^{2}+F 2^{2}+F 3^{2}}}{1.732}\right)
$$

The divisor 1.732 normalises the resultant values to a range between 0 and 100 , where 0 represents the 'worst' water quality and 100 represents the 'best' water quality. The CCME WQI index is very useful in tracking water quality changes at a given site over time and can also be used to compare directly among sites that employ the same variables and objectives (CCME 2001).

\section{Results}

\subsection{Stable isotopic composition}

The hydrogen and oxygen stable isotope composition of water samples are shown in table 1 . The reservoir water was the most enriched of the surface water samples, with mean of the $\delta \mathrm{D}$ and $\delta^{18} \mathrm{O}$ $-72.0 \%$ and $-9.6 \%$, respectively. The mean values of the $\delta \mathrm{D}$ and $\delta^{18} \mathrm{O}$ in river water were $-80.4 \%$ and $-11.3 \%$, respectively. The mean values of the $\delta \mathrm{D}$ and $\delta^{18} \mathrm{O}$ in lake water were the least $(-83.4 \% 0$ and $-12.0 \%$, respectively). The $\delta^{18} \mathrm{O}$ value of spring samples were the least, with the mean value $-12.4 \%$. However, the oxygen stable isotope in shallow groundwater was close to deep groundwater, 
Table 1. The location and stable isotopic composition of water samples.

\begin{tabular}{|c|c|c|c|c|c|c|c|c|}
\hline No. & $\begin{array}{l}\text { Sample } \\
\text { type }^{\mathrm{a}}\end{array}$ & $\begin{array}{l}\text { Latitude } \\
\qquad(\mathrm{N})\end{array}$ & $\begin{array}{l}\text { Longitude } \\
\text { (E) }\end{array}$ & $\begin{array}{l}\text { Elevation } \\
\qquad(\mathrm{m})^{\mathrm{b}}\end{array}$ & $\begin{array}{l}\text { Well depth } \\
\text { (m) }\end{array}$ & $\begin{array}{c}\text { Water } \\
\text { temperature }\left({ }^{\circ} \mathrm{C}\right)\end{array}$ & $\begin{array}{l}\delta \mathrm{D} \\
(\%)\end{array}$ & $\begin{array}{l}\delta^{18} \mathrm{O} \\
(\% 00)\end{array}$ \\
\hline L1 & LW & $43^{\circ} 46^{\prime} 02.3^{\prime \prime}$ & $126^{\circ} 49^{\prime} 0.5^{\prime \prime}$ & 263 & & 18.6 & -80.6 & -11.6 \\
\hline $\mathrm{L} 2$ & LW & $43^{\circ} 37^{\prime} 36.3^{\prime \prime}$ & $127^{\circ} 0^{\prime} 02.7^{\prime \prime}$ & 260 & & 17.0 & -80.4 & -11.8 \\
\hline L3 & LW & $43^{\circ} 35^{\prime} 18.0^{\prime \prime}$ & $127^{\circ} 13^{\prime} 17.2^{\prime \prime}$ & 263 & & 17.2 & -80.1 & -11.3 \\
\hline L4 & LW & $42^{\circ} 18^{\prime} 10.2^{\prime \prime}$ & $127^{\circ} 04^{\prime} 40.9^{\prime \prime}$ & 410 & & 15.6 & -92.5 & -13.3 \\
\hline $\mathrm{S} 1$ & $\mathrm{RE}$ & $44^{\circ} 29^{\prime} 03.2^{\prime \prime}$ & $125^{\circ} 13^{\prime} 30.4^{\prime \prime}$ & 172 & & 19.6 & -59 & -7.2 \\
\hline $\mathrm{S} 2$ & $\mathrm{RE}$ & $42^{\circ} 27^{\prime} 43.1^{\prime \prime}$ & $127^{\circ} 0^{\prime} 33.3^{\prime \prime}$ & 416 & & 16.7 & -85.1 & -12 \\
\hline $\mathrm{R} 1$ & RW & $44^{\circ} 14^{\prime} 21.6^{\prime \prime}$ & $125^{\circ} 14^{\prime} 22.1^{\prime \prime}$ & 173 & & 20.0 & -66.2 & -8.4 \\
\hline $\mathrm{R} 2$ & RW & $44^{\circ} 36^{\prime} 19.7^{\prime \prime}$ & $125^{\circ} 27^{\prime} 05.7^{\prime \prime}$ & 153 & & 20.1 & -63.3 & -8.2 \\
\hline $\mathrm{R} 3$ & RW & $44^{\circ} 31^{\prime} 25.7^{\prime \prime}$ & $125^{\circ} 45^{\prime} 21.4^{\prime \prime}$ & 164 & & 19.5 & -65.1 & -8.5 \\
\hline $\mathrm{R} 4$ & RW & $44^{\circ} 47^{\prime} 22.5^{\prime \prime}$ & $126^{\circ} 01^{\prime} 37.4^{\prime \prime}$ & 152 & & 12.9 & -80 & -11.2 \\
\hline $\mathrm{R} 5$ & RW & $44^{\circ} 50^{\prime} 59.9^{\prime \prime}$ & $126^{\circ} 37^{\prime} 37.3^{\prime \prime}$ & 170 & & 20.0 & -63.9 & -7.8 \\
\hline $\mathrm{R} 6$ & RW & $44^{\circ} 39^{\prime} 35.2^{\prime \prime}$ & $126^{\circ} 18^{\prime} 50.9^{\prime \prime}$ & 163 & & 12.5 & -81.3 & -11.5 \\
\hline $\mathrm{R} 7$ & RW & $44^{\circ} 30^{\prime} 47.8^{\prime \prime}$ & $126^{\circ} 25^{\prime} 30.6^{\prime \prime}$ & 161 & & 11.7 & -81.6 & -11.7 \\
\hline $\mathrm{R} 8$ & RW & $44^{\circ} 14^{\prime} 34.2^{\prime \prime}$ & $126^{\circ} 28^{\prime} 47.9^{\prime \prime}$ & 168 & & 11.2 & -81.8 & -11.8 \\
\hline $\mathrm{R} 9$ & RW & $44^{\circ} 03^{\prime} 47.0^{\prime \prime}$ & $126^{\circ} 27^{\prime} 24.8^{\prime \prime}$ & 173 & & 10.2 & -82.6 & -12 \\
\hline $\mathrm{R} 10$ & RW & $43^{\circ} 56^{\prime} 50.8^{\prime \prime}$ & $126^{\circ} 28^{\prime} 47.2^{\prime \prime}$ & 177 & & 9.6 & -82.9 & -11.6 \\
\hline R11 & RW & $43^{\circ} 43^{\prime} 4.3^{\prime \prime}$ & $127^{\circ} 19^{\prime} 29.4^{\prime \prime}$ & 271 & & 14.3 & -77.2 & -11.1 \\
\hline $\mathrm{R} 12$ & RW & $42^{\circ} 02^{\prime} 29.1^{\prime \prime}$ & $128^{\circ} 03^{\prime} 43.0^{\prime \prime}$ & 1942 & & 5.7 & -100.7 & -14.6 \\
\hline $\mathrm{R} 13$ & RW & $42^{\circ} 02^{\prime} 36.7^{\prime \prime}$ & $128^{\circ} 03^{\prime} 52.6^{\prime \prime}$ & 1896 & & 4.3 & -100.9 & -14.9 \\
\hline $\mathrm{R} 14$ & RW & $42^{\circ} 24^{\prime} 34^{\prime \prime}$ & $128^{\circ} 06^{\prime} 53.9^{\prime \prime}$ & 717 & & 9.1 & -97.3 & -14.1 \\
\hline $\mathrm{R} 15$ & RW & $42^{\circ} 20^{\prime} 45.1^{\prime \prime}$ & $127^{\circ} 15^{\prime} 22.9^{\prime \prime}$ & 426 & & 9.2 & -96.3 & -13.7 \\
\hline $\mathrm{R} 16$ & RW & $42^{\circ} 20^{\prime} 20.3^{\prime \prime}$ & $127^{\circ} 15^{\prime} 33.3^{\prime \prime}$ & 439 & & 18.6 & -84.4 & -12.2 \\
\hline $\mathrm{R} 17$ & RW & $42^{\circ} 20^{\prime} 40.5^{\prime \prime}$ & $127^{\circ} 13^{\prime} 15.0^{\prime \prime}$ & 420 & & 11.4 & -95.7 & -14 \\
\hline $\mathrm{R} 18$ & RW & $42^{\circ} 44^{\prime} 16.2^{\prime \prime}$ & $127^{\circ} 13^{\prime} 39.9^{\prime \prime}$ & 301 & & 5.5 & -88.9 & -12.4 \\
\hline R19 & RW & $42^{\circ} 57^{\prime} 46.6^{\prime \prime}$ & $127^{\circ} 06^{\prime} 29.9^{\prime \prime}$ & 275 & & 9.1 & -87.6 & -12.2 \\
\hline $\mathrm{R} 20$ & RW & $42^{\circ} 57^{\prime} 20.9^{\prime \prime}$ & $126^{\circ} 45^{\prime} 01.7^{\prime \prime}$ & 269 & & 21.1 & -67.2 & -9 \\
\hline $\mathrm{R} 21$ & RW & $43^{\circ} 24^{\prime} 07.4^{\prime \prime}$ & $125^{\circ} 57^{\prime} 14.8^{\prime \prime}$ & 234 & & 20.2 & -71.2 & -9.8 \\
\hline $\mathrm{R} 22$ & RW & $43^{\circ} 31^{\prime} 43.5^{\prime \prime}$ & $125^{\circ} 51^{\prime} 57.8^{\prime \prime}$ & 214 & & 21.2 & -71.5 & -10 \\
\hline $\mathrm{R} 23$ & RW & $43^{\circ} 42^{\prime} 18.9^{\prime \prime}$ & $125^{\circ} 59^{\prime} 28.9^{\prime \prime}$ & 232 & & 18.5 & -76.5 & -11 \\
\hline $\mathrm{R} 24$ & RW & $43^{\circ} 47^{\prime} 33.5^{\prime \prime}$ & $125^{\circ} 48^{\prime} 13.3^{\prime \prime}$ & 199 & & 25.3 & -62.1 & -8.5 \\
\hline Q1 & $\mathrm{SP}$ & $42^{\circ} 02^{\prime} 36.7^{\prime \prime}$ & $128^{\circ} 03^{\prime} 52.6^{\prime \prime}$ & 1896 & & 75.0 & -101.5 & -14.6 \\
\hline Q2 & SP & $42^{\circ} 20^{\prime} 44.1^{\prime \prime}$ & $127^{\circ} 13^{\prime} 03.7^{\prime \prime}$ & 436 & & 11.6 & -81.6 & -11.8 \\
\hline Q3 & $\mathrm{SP}$ & $42^{\circ} 57^{\prime} 45.7^{\prime \prime}$ & $127^{\circ} 07^{\prime} 11.6^{\prime \prime}$ & 272 & & 9.3 & -83.3 & -11.8 \\
\hline Q4 & $\mathrm{SP}$ & $43^{\circ} 31^{\prime} 42.9^{\prime \prime}$ & $125^{\circ} 52^{\prime} 02.4^{\prime \prime}$ & 220 & & 11.3 & -76.1 & -11.2 \\
\hline G1 & GW & $44^{\circ} 14^{\prime} 26.5^{\prime \prime}$ & $125^{\circ} 14^{\prime} 25.9^{\prime \prime}$ & 180 & 25 & 8.6 & -73.8 & -10.2 \\
\hline G2 & GW & $44^{\circ} 36^{\prime} 15.3^{\prime \prime}$ & $125^{\circ} 27^{\prime} 53.2^{\prime \prime}$ & 154 & 11 & 12.1 & -69.3 & -9.3 \\
\hline G3 & GW & $44^{\circ} 47^{\prime} 48.2^{\prime \prime}$ & $126^{\circ} 01^{\prime} 17.6^{\prime \prime}$ & 168 & 10 & 8.9 & -72.8 & -9.9 \\
\hline G4 & GW & $44^{\circ} 51^{\prime} 0.7^{\prime \prime}$ & $126^{\circ} 37^{\prime} 35.7^{\prime \prime}$ & 172 & 35 & 8.1 & -75.1 & -10.4 \\
\hline G5 & GW & $44^{\circ} 40^{\prime} 28.8^{\prime \prime}$ & $126^{\circ} 19^{\prime} 49.9^{\prime \prime}$ & 171 & 27 & 8.9 & -74.4 & -10.5 \\
\hline G6 & GW & $44^{\circ} 31^{\prime} 06.9^{\prime \prime}$ & $126^{\circ} 25^{\prime} 55.1^{\prime \prime}$ & 166 & 20 & 11.2 & -71.5 & -9.8 \\
\hline G7 & GW & $44^{\circ} 14^{\prime} 38.5^{\prime \prime}$ & $126^{\circ} 28^{\prime} 58.4^{\prime \prime}$ & 178 & 10 & 9.7 & -74.4 & -10.5 \\
\hline G8 & GW & $44^{\circ} 03^{\prime} 30.0^{\prime \prime}$ & $126^{\circ} 27^{\prime} 22.1^{\prime \prime}$ & 185 & 20 & 10.6 & -67.1 & -9.4 \\
\hline G9 & GW & $43^{\circ} 56^{\prime} 55.6^{\prime \prime}$ & $126^{\circ} 28^{\prime} 46.5^{\prime \prime}$ & 185 & 18 & 10.4 & -80 & -11.3 \\
\hline G10 & GW & $43^{\circ} 46^{\prime} 09.7^{\prime \prime}$ & $126^{\circ} 48^{\prime} 38.3^{\prime \prime}$ & 275 & 7 & 7.7 & -75.1 & -11 \\
\hline G11 & GW & $43^{\circ} 46^{\prime} 13.2^{\prime \prime}$ & $126^{\circ} 48^{\prime} 34.8^{\prime \prime}$ & 286 & 50 & 9.7 & -80 & -11.7 \\
\hline G12 & GW & $43^{\circ} 37^{\prime} 21.7^{\prime \prime}$ & $127^{\circ} 0^{\prime} 30.1^{\prime \prime}$ & 280 & 10 & 9.0 & -77.8 & -11.5 \\
\hline G13 & GW & $43^{\circ} 35^{\prime} 08.9^{\prime \prime}$ & $127^{\circ} 12^{\prime} 56.4^{\prime \prime}$ & 277 & 35 & 8.8 & -76.4 & -10.7 \\
\hline G14 & GW & $42^{\circ} 24^{\prime} 13.7^{\prime \prime}$ & $128^{\circ} 06^{\prime} 45.5^{\prime \prime}$ & 740 & 15 & 11.7 & -98.8 & -14.5 \\
\hline G15 & GW & $42^{\circ} 20^{\prime} 43.0^{\prime \prime}$ & $127^{\circ} 13^{\prime} 06.9^{\prime \prime}$ & 437 & 10 & 7.0 & -77.6 & -11.1 \\
\hline G16 & GW & $42^{\circ} 18^{\prime} 10.6^{\prime \prime}$ & $127^{\circ} 4^{\prime} 35.5^{\prime \prime}$ & 421 & 9.5 & 8.1 & -80.5 & -11.2 \\
\hline G17 & GW & $42^{\circ} 57^{\prime} 32.6^{\prime \prime}$ & $126^{\circ} 41^{\prime} 53.4^{\prime \prime}$ & 278 & 7 & 8.1 & -75.9 & -10.9 \\
\hline G18 & GW & $43^{\circ} 24^{\prime} 15.5^{\prime \prime}$ & $125^{\circ} 56^{\prime} 53.0^{\prime \prime}$ & 238 & 8 & 9.3 & -75.8 & -11 \\
\hline
\end{tabular}


Table 1. (Continued.)

\begin{tabular}{|c|c|c|c|c|c|c|c|c|}
\hline No. & $\begin{array}{l}\text { Sample } \\
\text { type }^{\mathrm{a}}\end{array}$ & $\begin{array}{l}\text { Latitude } \\
\qquad(\mathrm{N})\end{array}$ & $\begin{array}{l}\text { Longitude } \\
\text { (E) }\end{array}$ & $\begin{array}{l}\text { Elevation } \\
\qquad(\mathrm{m})^{\mathrm{b}}\end{array}$ & $\begin{array}{l}\text { Well depth } \\
\text { (m) }\end{array}$ & $\begin{array}{c}\text { Water } \\
\text { temperature }\left({ }^{\circ} \mathrm{C}\right)\end{array}$ & $\begin{array}{l}\delta \mathrm{D} \\
(\%)\end{array}$ & $\begin{array}{c}\delta^{18} \mathrm{O} \\
(\% 00)\end{array}$ \\
\hline G19 & GW & $43^{\circ} 32^{\prime} 30.4^{\prime \prime}$ & $125^{\circ} 52^{\prime} 05.9^{\prime \prime}$ & 220 & 13 & 8.6 & -77.6 & -11.1 \\
\hline D1 & GW & $43^{\circ} 37^{\prime} 33.7^{\prime \prime}$ & $127^{\circ} 0^{\prime} 10.4^{\prime \prime}$ & 275 & 75 & 16.6 & -75.3 & -11.1 \\
\hline D2 & GW & $42^{\circ} 18^{\prime} 09.7^{\prime \prime}$ & $127^{\circ} 04^{\prime} 37.1^{\prime \prime}$ & 418 & 76 & 10.3 & -82.2 & -11.7 \\
\hline D3 & GW & $43^{\circ} 25^{\prime} 11.0^{\prime \prime}$ & $125^{\circ} 55^{\prime} 30.2^{\prime \prime}$ & 235 & 100 & 13.4 & -73.7 & -10.4 \\
\hline
\end{tabular}

a: LW, RE, RW, SP, and GW stand for lake water, reservoir water, river water, spring and groundwater, respectively.

$\mathrm{b}$ : Elevation is in meters above sea level.

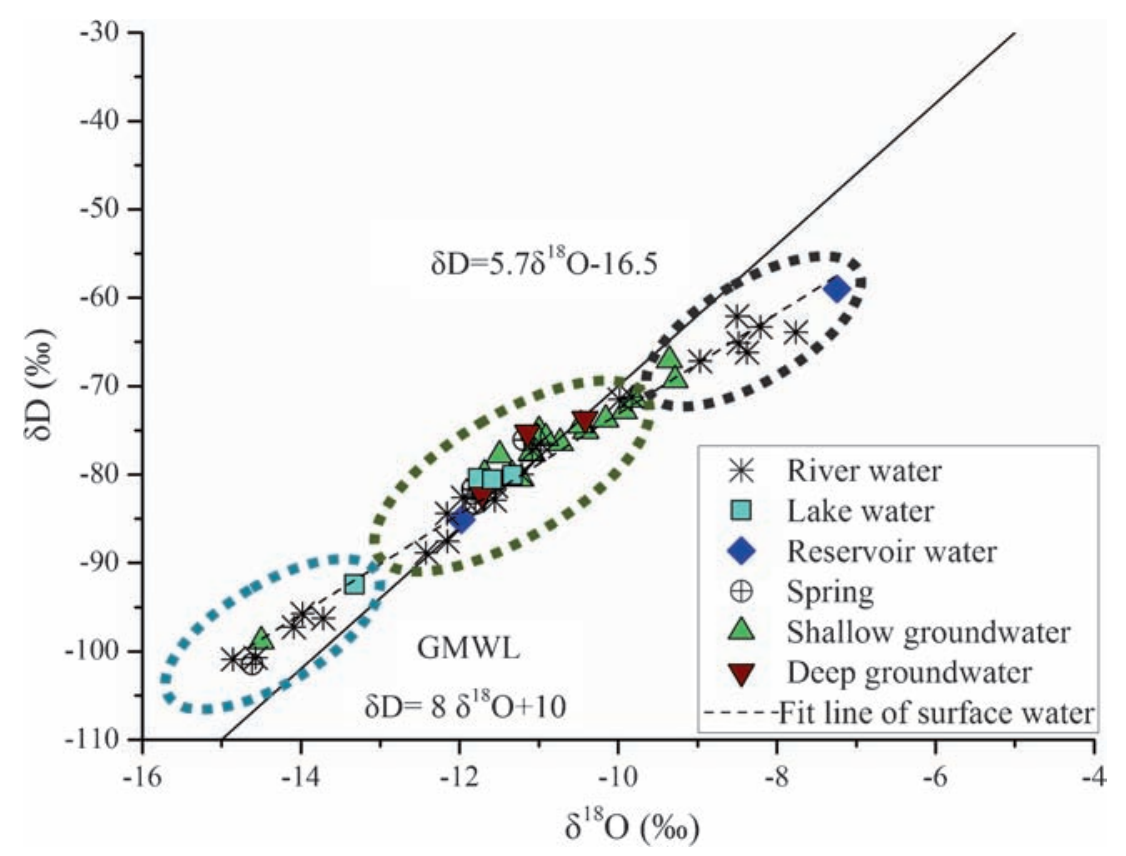

Figure 5. The scatter plots of $\delta^{18} \mathrm{O}$ and $\delta \mathrm{D}$.

with the $\delta^{18} \mathrm{O}$ value $-10.8 \%$ and $-10.6 \%$, respectively. The stable isotopes in reservoir waters were the most enriched, while the springs were the most depleted.

The isotopic composition of oxygen $\left(\delta^{18} \mathrm{O}\right)$ and hydrogen $(\delta \mathrm{D})$ in water samples were heterogenic spatially. The relationship between $\delta^{18} \mathrm{O}$ and $\delta \mathrm{D}$ in water samples are divided into three groups (figure 5). Most water samples in the upper reaches, fall on the left-bottom area of the figure, with the most depleted stable isotopes. The stable isotope composition of the water samples, collected in the downstream, fall on the right-up area of the figure. Most groundwater and surface water samples fall in the middle part of the figure. The fit line of surface water samples is $\delta \mathrm{D}=5.7 \delta^{18} \mathrm{O}-16.5$. The $\delta \mathrm{D}$ and $\delta^{18} \mathrm{O}$ values at the cross point of fit line of surface water and global meteoric water line (GMWL) is $-82.0 \%$ and $-11.5 \%$, respectively.

\subsection{Characteristics of major ions}

The major ions and total dissolved solid concentrations of surface water and groundwater samples are shown in table 2 . The dominating cation and anion in water samples were $\mathrm{Ca}^{2+}$ and $\mathrm{HCO}_{3}^{-}$, respectively. The mean value of TDS in surface water was $179.62 \mathrm{mg} / \mathrm{L}$, while in the groundwater it was $383.95 \mathrm{mg} / \mathrm{L}$. The TDS concentration in groundwater was more than twice of surface water. The mean value of $\mathrm{NO}_{3}^{-}$concentration in surface water was $4.03 \mathrm{mg} / \mathrm{L}$; however, the mean value in groundwater was $30.05 \mathrm{mg} / \mathrm{L}$. The value of $\mathrm{NO}_{3}^{-}$concentration in groundwater was more than seven times greater than that in surface water. The mean value of major ion concentration in groundwater was larger than that in surface water.

The water type of most water samples were $\mathrm{Ca}-\mathrm{HCO}_{3}$. The water samples in the green circle located at the right-bottom of the diamond, include two river waters (R12, R14), one shallow groundwater (G1), and one thermal spring (Q1). The water type of the river waters and shallow groundwater was $\mathrm{Na}-\mathrm{HCO}_{3}$; however, the water type of the thermal spring was $\mathrm{Na}-\mathrm{Cl}$. The evolution of water types is from the $\mathrm{Na}-\mathrm{HCO}_{3}$ to $\mathrm{Ca}$ $(\mathrm{Mg})-\mathrm{HCO}_{3}$ and $\mathrm{Ca}(\mathrm{Mg})-\mathrm{Cl}\left(\mathrm{SO}_{4}\right)$. 


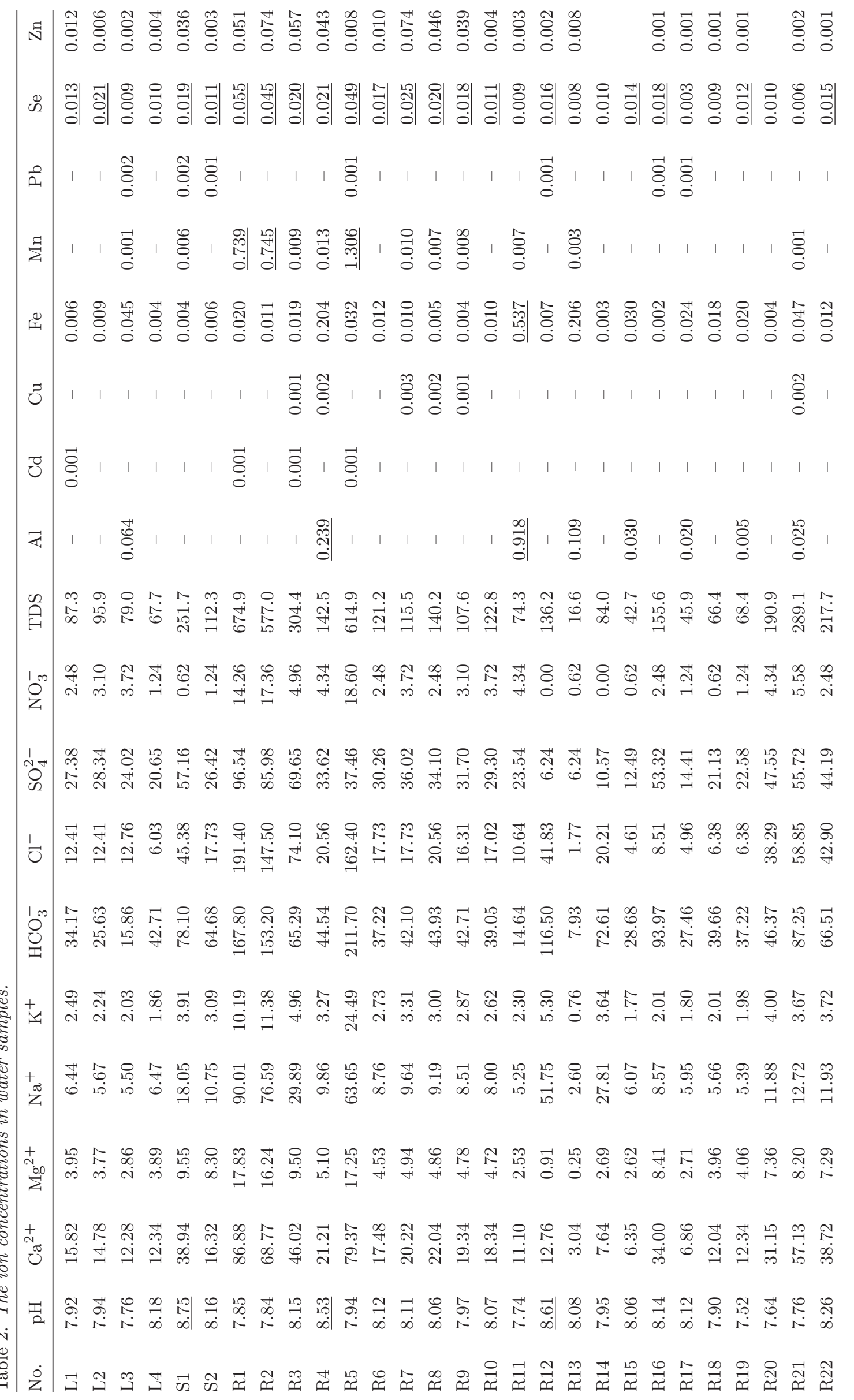




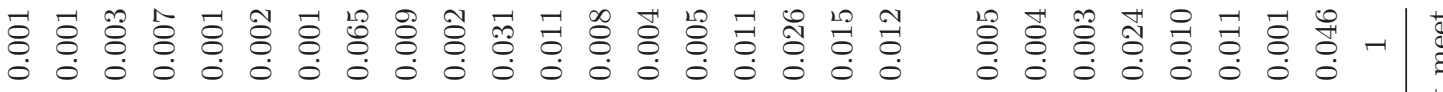

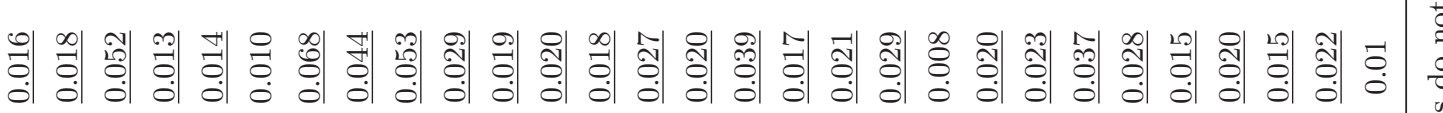

高

홓홓ㅎำ

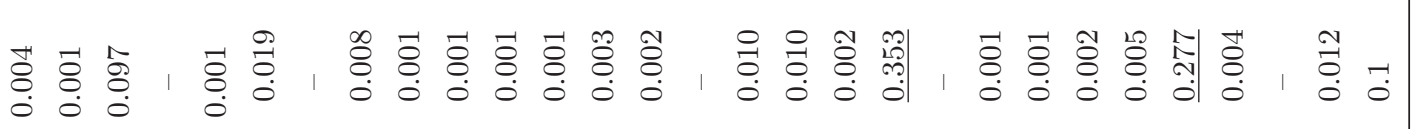

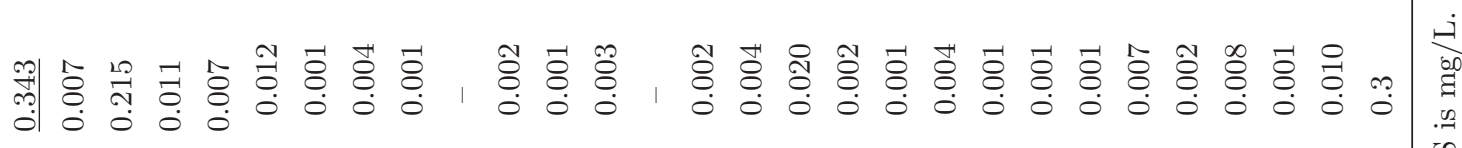

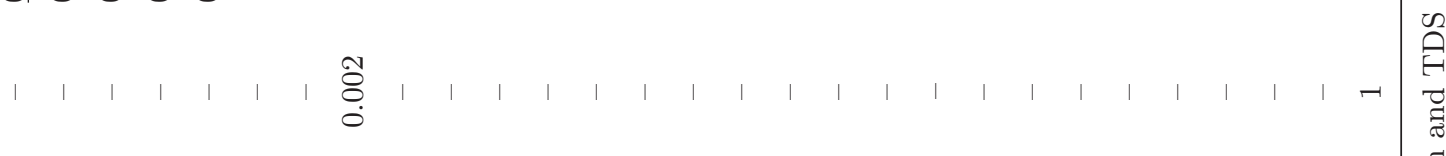

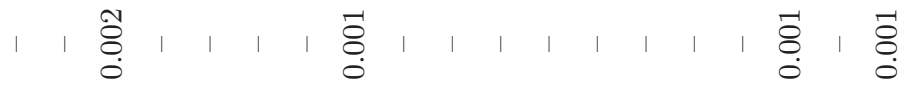

$\frac{\infty}{6} \mid$

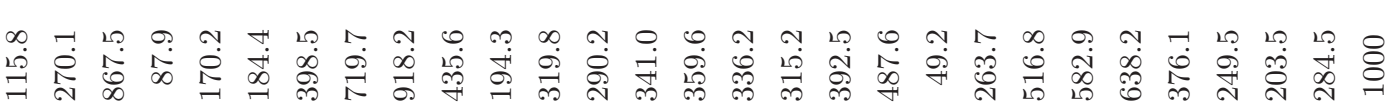

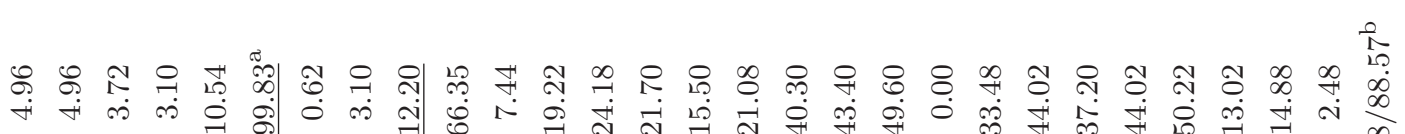
+

온

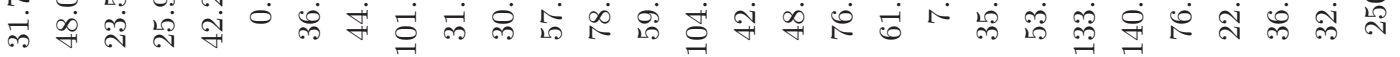

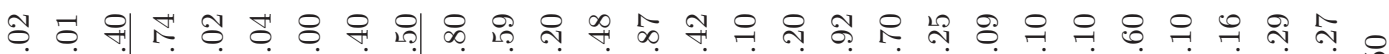

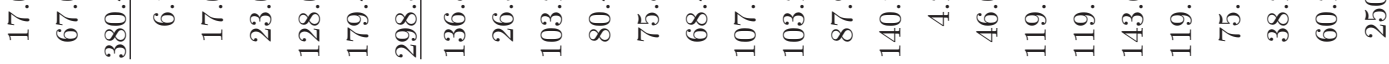
\&

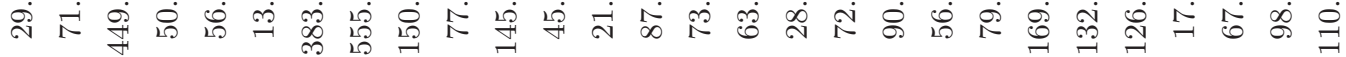

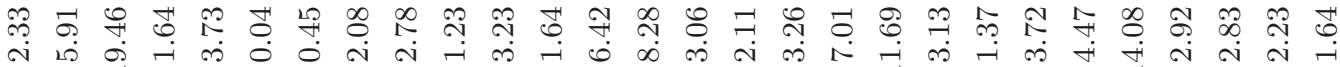
\& 8 \&

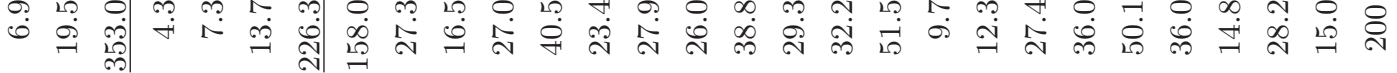
눙 ๑

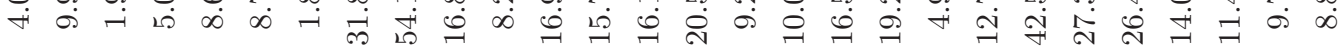

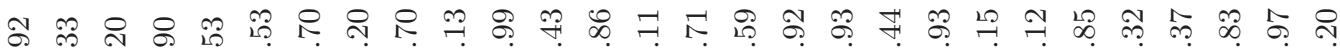

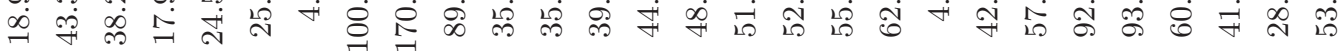
పా

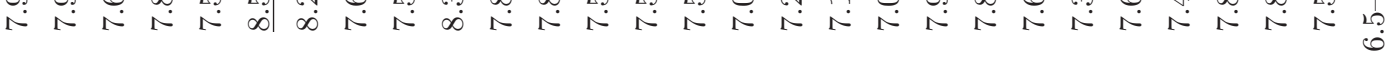




\subsection{Water quality index}

The CCME water quality index was applied to compare the surface water and groundwater quality for drinking. The concentrations of water quality parameters and objective values were shown in table 2 . The numbers of failed variables of surface water and groundwater were 5 and 6 , respectively. The total number of water quality variables was 14. Consequently, the $F 1$ (scope) values of surface water and groundwater were 37.71 and 42.86 , respectively. The numbers of tests of surface water and groundwater not meeting objectives were 32 and 33, respectively. The total numbers of test of surface water and groundwater were 308 and 260, respectively. The missing data was not included in the total number of tests. Therefore, the F2 (frequency) of surface water and groundwater were 10.39 and 12.69 , respectively.

To determine the F3, the normalised sum of excursions (nse) was calculated first. The nse of surface water and groundwater were 0.182 and 0.187 , respectively. With the three factors now obtained, the CCME WQI value can be calculated. The water quality index of surface water and groundwater were 77 and 73, respectively. The surface water and groundwater quality was 'Fair' (CCME WQI value 65-79), indicating that the water quality was usually protected but occasionally threatened or impaired. However, the surface water value was larger than the groundwater. Compared to the surface water, the concentrations of $\mathrm{Na}^{+}$, $\mathrm{Cl}^{-}$and $\mathrm{NO}_{3}^{-}$in the groundwater were larger.

\section{Discussion}

\subsection{Relationship between surface water and groundwater}

The isotope tracers $\left(\delta^{18} \mathrm{O}, \delta \mathrm{D}\right)$ and hydrochemical analyses were conducted to assess the groundwatersurface water interaction (Rodgers et al. 2004; Petelet-Giraud et al. 2007; Einsiedl 2012; Cook 2013). Furthermore, the two-component equation based on isotopic mass balance was applied to quantify the relationship between surface water and groundwater (Clark and Fritz 1997). The parameters of oxygen stable isotope and conservative $\mathrm{Cl}^{-}$anion were used to determine the relationship between surface water and groundwater. The characteristic of hydrochemical and $\delta^{18} \mathrm{O}$ value is shown in figure 6 .

At the Wujin village, the groundwater table was $6 \mathrm{~m}$ which was higher than the river stage height, indicating that the shallow groundwater may discharge to the river. The $\delta^{18} \mathrm{O}$ values of river water R4, groundwater G3 and the river water R6
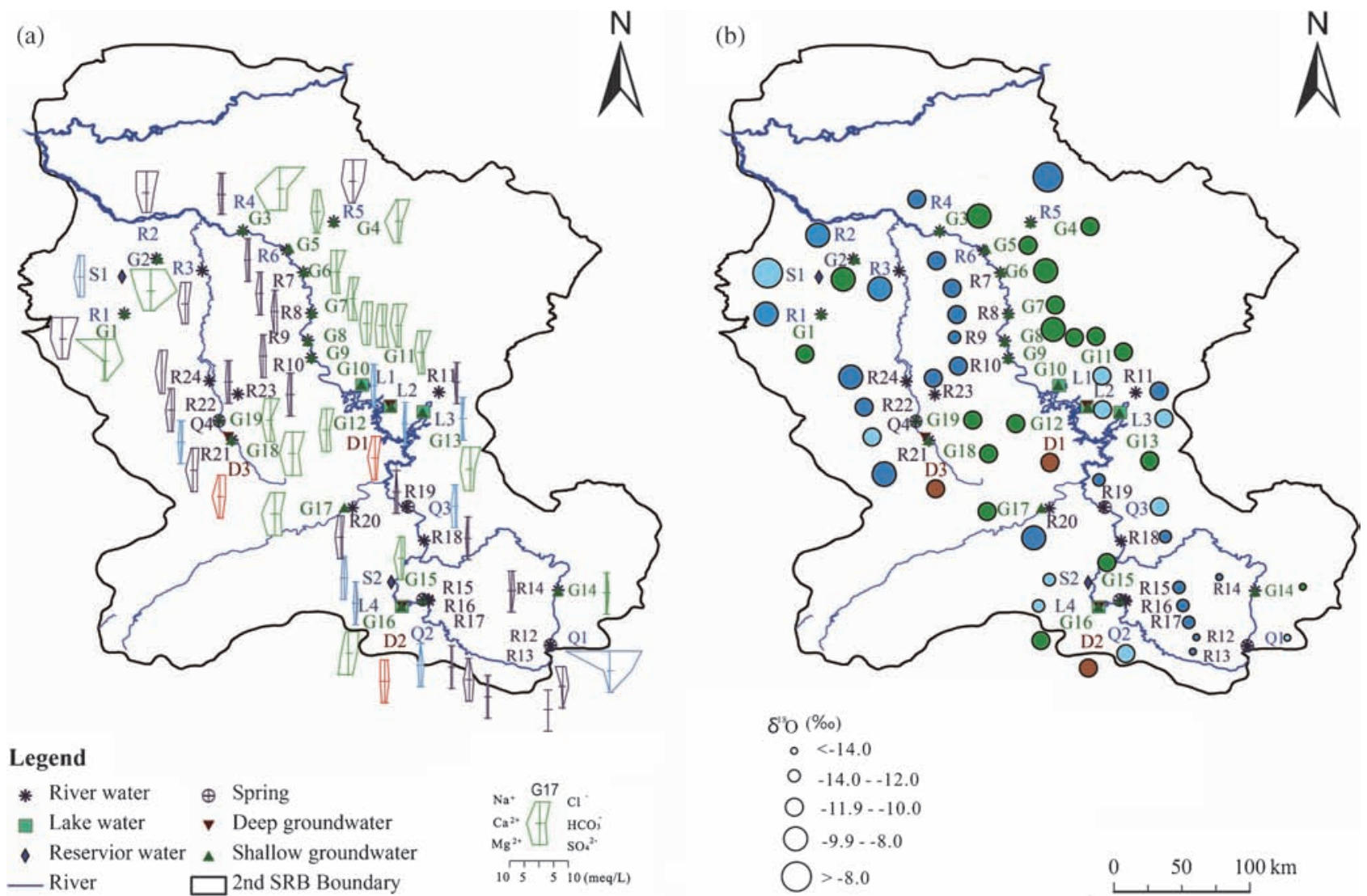

Legend

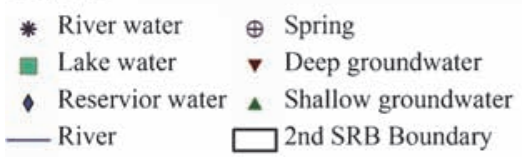

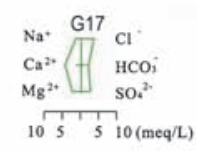

Figure 6. (a) Stiff diagram and (b) $\delta^{18} \mathrm{O}$ value of water samples. 
from the upper reaches were $-11.2 \%,-9.9 \%$, and $-1.5 \%$, respectively. The contributions of shallow groundwater and river water from the upper reaches to the river water at Wujin village were $18.7 \%$ and $81.3 \%$, respectively, according to the twocomponent mixing equation of oxygen stable isotope. The river water ( $\mathrm{R} 8)$ may recharge from the shallow groundwater (G7) and the river water (R9) from upper reaches. The percentages of the shallow groundwater (G7) and river water (R9) were $13.3 \%$ and $86.7 \%$, respectively.

The water tables of shallow groundwater (G12) and Songhua Lake (L2) were about 270 and $260 \mathrm{~m}$, respectively. However, the deep groundwater (D1) table was $200 \mathrm{~m}$ at the Ailin village. The deep groundwater may be the mixture of shallow groundwater and lake water, according to the water tables. The oxygen stable isotope contents in surface water and groundwater were not significantly different. Thus, the conservative anion, $\mathrm{Cl}^{-}$, was used to examine the interaction between surface water and groundwater. The contributions of shallow groundwater and lake water to deep groundwater were $83.1 \%$ and $16.9 \%$, respectively. The deep groundwater (D2) may also recharge from lake water (L4) and shallow groundwater (G16). The contributions of lake water (L4) and shallow groundwater (G16) were $23.8 \%$ and $76.2 \%$, respectively, according to the oxygen stable isotope contents. Meanwhile, the contributions of shallow groundwater (G18) and river water (R21) to the deep groundwater (D3) were both $50 \%$ at the Yinma River, one of the tributaries of the Second Songhua River.

\subsection{Mixing of surface water and groundwater}

The environmental tracers were applied to assess the water mixing. The water mixing occurs at various scales (Woessner 2000; Liu et al. 2006; Cartwright et al. 2010). The relationship and the percentage in the Second Songhua River were revealed by oxygen stable isotope and conservative anion. Furthermore, the PHREEQC model was used to analyse the simulated hydrochemical composition. The moles of all elements and the mass of water are multiplied by the solution's mixing fraction. The charge imbalance of each solution is multiplied by the mixing fraction and all the imbalances are then summed to calculate the charge imbalance of the mixture. All of the IBEs of the simulated mixing water were $<5 \%$. The $r e$ and the sde were used to measure the accuracy of the simulation.

The maximum absolute re value of $\mathrm{K}^{+}$cation was water sample D3, with the value 4.4 (table 3 ). The minimum absolute re value of $\mathrm{Ca}^{2+}$ cation was water sample $\mathrm{R} 8$, with the value 0 . The sde value of water sample $\mathrm{R} 8$ was the least, with the value 1.92 . The sde value of water sample D2 was the largest, with the value 27.94. The accuracies of water samples in the upper reaches (D3, D2) were lower than the water samples in the middle reaches and downstream (D1, R8 and R4). The water in upper reaches may partly recharge from the allogenic water (Chen et al. 2011). The groundwater circulation, parameters of the model, etc., may influence the accuracy of the simulation.

\subsection{Water quality of surface water and groundwater}

Not only was the CCME WQI used to compare the surface water and groundwater quality, but also the standard was applied to assess the water quality for drinking. Most surface water and ground water were good for drinking, but there were

Table 3. The simulated major ions composition by PHREEQC mix process.

\begin{tabular}{|c|c|c|c|c|c|c|c|c|}
\hline Sample no. & $\mathrm{Ca}^{2+}$ & $\mathrm{Mg}^{2+}$ & $\mathrm{Na}^{+}$ & $\mathrm{K}^{+}$ & $\mathrm{HCO}_{3}^{-}$ & $\mathrm{SO}_{4}^{2-}$ & $\mathrm{Cl}^{-}$ & $s d e^{*}$ \\
\hline \multirow[t]{2}{*}{$\mathrm{R} 4$} & 46.04 & 13.78 & 12.21 & 2.73 & 71.07 & 43.55 & 70.00 & $\S$ \\
\hline & 21.21 & 5.10 & 9.86 & 3.27 & 44.54 & 33.62 & 20.56 & $\dagger$ \\
\hline re & -1.17 & -1.70 & -0.24 & 0.16 & -0.60 & -0.30 & -2.40 & 17.54 \\
\hline \multirow[t]{2}{*}{$\mathrm{R} 8$} & 22.01 & 6.21 & 10.47 & 3.33 & 48.48 & 37.86 & 24.78 & $\S$ \\
\hline & 22.04 & 4.86 & 9.19 & 3.00 & 43.93 & 34.10 & 20.56 & $\dagger$ \\
\hline re & 0.00 & -0.28 & -0.14 & -0.11 & -0.10 & -0.11 & -0.21 & 1.92 \\
\hline \multirow[t]{2}{*}{ D1 } & 48.84 & 14.36 & 27.67 & 6.19 & 78.68 & 68.49 & 74.99 & $\S$ \\
\hline & 41.83 & 11.45 & 14.86 & 2.83 & 67.73 & 22.58 & 75.16 & $\dagger$ \\
\hline re & -0.17 & -0.25 & -0.86 & -1.19 & -0.16 & -2.03 & 0.00 & 15.71 \\
\hline \multirow[t]{2}{*}{ D2 } & 46.37 & 33.31 & 22.42 & 3.27 & 169.10 & 45.81 & 92.00 & $\S$ \\
\hline & 28.97 & 9.79 & 28.27 & 2.23 & 98.85 & 36.02 & 38.29 & $\dagger$ \\
\hline re & -0.60 & -2.40 & 0.21 & -0.47 & -0.71 & -0.27 & -1.40 & 27.94 \\
\hline \multirow[t]{2}{*}{ D3 } & 75.07 & 17.29 & 31.34 & 8.86 & 129.90 & 97.82 & 101.00 & $\S$ \\
\hline & 53.20 & 8.82 & 15.08 & 1.64 & 110.40 & 32.66 & 60.27 & $\dagger$ \\
\hline re & -0.41 & -0.96 & -1.08 & -4.40 & -0.18 & -2.00 & -0.68 & 20.67 \\
\hline
\end{tabular}

$s d e^{*}$ is the standard deviation of the error; $r e$ is the relative error; $\S$ indicates the calculated value of the ion; $\dagger$ is the measured concentration of the ion; and the unit of ion concentration is $\mathrm{mg} / \mathrm{L}$. 
five surface water and two groundwater samples exceeding the guidelines, according to the standard (Ministry of Health of the People's Republic of China 2006). The five surface water samples (R1, R2, R5, R11, R23) beyond the drinking water supply were exceeding the concentrations of $\mathrm{Al}$, $\mathrm{Fe}, \mathrm{Mn}$ and Se. Two groundwater samples (G13, G19) were exceeding the concentrations of $\mathrm{Mn}$ and Se. The aluminium (Al) exposure is a risk factor for the development or acceleration of onset of Alzheimer disease in humans. Manganese $(\mathrm{Mn})$ is usually occurring with iron (Fe), and it is used principally in the manufacture of iron and steel alloys (World Health Organization 2011). The concentrations of nitrate $\left(\mathrm{NO}_{3}^{-}\right)$in the groundwater samples (G3, Q4) sampled in the dry land, were exceeding the guidelines. These water samples exceeding drinking water quality standards may be affected by agricultural and built-up land uses in basin (Bu et al. 2014).

The interaction between surface water and groundwater influences the composition of ions in the mixing water. The groundwater (G3) was exceeding the concentration of $\mathrm{NO}_{3}^{-}$(with the value $112.20 \mathrm{mg} / \mathrm{L}$ ). During the groundwater flow in the aquifer, the anammox and denitrification were sufficient to reduce inorganic nitrogen concentrations substantially. The denitrification activities produce $\mathrm{N}_{2}$ in the aquifer (Smith et al. 2015). When the groundwater (G3) interacted with river water (R6), the concentration of nitrate in the mixture river water (R4) was below the guideline (with the value $4.34 \mathrm{mg} / \mathrm{L}$ ). Furthermore, the hydrochemical composition in water is affected by geological settings and geochemical processes (Senthilkumar and Elango 2013; Senthilkumar et al. 2015). The trace element selenium is essential for humans. At the same time, high intakes of selenium are also associated with a number of specific diseases and the potential for adverse effects (World Health Organization 2011). The Second Songhua River basin is a seleniferous area. Most concentrations of selenium in water are higher than $10 \mu \mathrm{g} / \mathrm{l}$ (table 2). The concentration of Se in the mixture water is exceeding the guidelines, because the concentrations of Se in the source water are high.

\section{Conclusions}

The interactions between surface water and groundwater not only influence the water quantity, but also affect the water quality. The compositions of stable isotopes $\left(\delta \mathrm{D}, \delta^{18} \mathrm{O}\right)$ and major ions were analysed in the Second Songhua River basin. The deep groundwater is mainly recharged from shallow groundwater in the middle and upper reaches. However, the shallow groundwater may discharge to rivers in the downstream. Nevertheless, the contribution of shallow groundwater is less than $20 \%$. The runoff from upper reaches mainly contributes the river flow in the downstream. The CCME WQI indicated that the surface water and groundwater quality was 'Fair'. The mixing process between surface water and groundwater was simulated by the PHREEQC code. The accuracy of simulations in the middle reaches and downstream is better than the simulations in the upper reaches. The interaction between surface water and groundwater influences the composition of ions in the mixing water, furthermore, affects the water quality with other factors.

\section{Acknowledgements}

This research was supported by the Main Direction Program of Knowledge Innovation of Chinese Academy of Sciences (No. KZCX2-YW-Q06-1), the Key Program of National Natural Science Foundation of China (No. 40830636), the Joint Program of Tianjin Science Foundation (No. 15JCQNJC44200), National Natural Science Foundation of China (No. 41372373), the Innovation Team Training Plan of the Tianjin Education Committee (No. TD12-5037) and the Doctoral Found of Tianjin Normal University (No. 52XB1401).

\section{References}

Akkoyunlu A and Akiner M E 2012 Pollution evaluation in streams using water quality indices: A case study from Turkey's Sapanca Lake Basin; Ecol. Indic. 18 501-511.

Ayenew T, Kebede S and Alemyahu T 2008 Environmental isotopes and hydrochemical study applied to surface water and groundwater interaction in the Awash River basin; Hydrol. Process. 22 1548-1563.

Bai Y, Wang J, Li J and Teng Y 2011 Chemical characteristics of shallow groundwater and current pollution situation along the Second Songhua River (in Chinese); South-to-North Water Diversion and Water Science $\&$ Technology 9 116-119.

Banks E W, Simmons C T, Love A J and Shand P 2011 Assessing spatial and temporal connectivity between surface water and groundwater in a regional catchment: Implications for regional scale water quantity and quality; J. Hydrol. 404 30-49.

Baskaran S, Ransley T, Brodie R S and Baker P 2009 Investigating groundwater-river interactions using environmental tracers; Austr. J. Earth Sci. 56 13-19.

Brunner P, Cook P G and Simmons C T 2011 Disconnected surface water and groundwater: From theory to practice; Ground Water 49 460-467.

Bu H, Meng W, Zhang Y and Wan J 2014 Relationships between land use patterns and water quality in the Taizi River basin, China; Ecol. Indic. 41 187-197.

Cartwright I, Weaver T, Cendón D I and Swane I 2010 Environmental isotopes as indicators of inter-aquifer mixing, Wimmera region, Murray Basin, southeast Australia; Chem. Geol. 277 214-226. 
CCME 2001 Canadian water quality guidelines for the protection of aquatic life: CCME Water Quality Index 1.0, User's Manual; In: Canadian Environmental Quality Guidelines, Canadian Council of Ministers of the Environment, Winnipeg, Manitoba.

Chen J, Liu X, Wang C, Rao W, Tan H, Dong H, Sun X, Wang Y and Su Z 2011 Isotopic constraints on the origin of groundwater in the Ordos basin of northern China; Environ. Earth Sci. 66 505-517.

Clark I D and Fritz P 1997 Environmental isotopes in hydrology; Lewis Publishers, New York.

Cook P G 2013 Estimating groundwater discharge to rivers from river chemistry surveys; Hydrol. Process. 27 3694-3707.

Cude C G 2001 Oregon Water Quality Index: A tool for evaluating water quality management effectiveness; $J$. Am. Water Resour. Assoc. 37 125-137.

Einsiedl F 2012 Sea-water/groundwater interactions along a small catchment of the European Atlantic coast; Appl. Geochem. 27 73-80.

Gardner K M 1999 The importance of surface water groundwater interactions issue paper; Environmental Protection Agency, Seattle.

GEMS 2007 Global drinking water quality index development and sensitivity analysis report, United Nations Environment Programme Global Environment Monitoring System/Water Programme Office, Burlington, Ontario.

Institute of Hydrogeology and Environmental Geology 1979 The hydrogeological atlas of China (in Chinese); Geological Publishing House, Beijing.

Krause S, Bronstert A and Zehe E 2007 Groundwatersurface water interactions in a north German lowland floodplain - Implications for the river discharge dynamics and riparian water balance; J. Hydrol. 347 404-417.

Lange M 2005 On the uncertainty of wind power predictions - Analysis of the forecast accuracy and statistical distribution of errors; J. Sol. Energ.-T Asme. 127177.

Lin C, He M, Zhou Y, Guo W and Yang Z 2008 Distribution and contamination assessment of heavy metals in sediment of the Second Songhua River, China; Environ. Monit. Assess. 137 329-342.

Liu J and Yu J 1999 Dynamic variation of nitrogen content in the Second Songhua River; Chinese Geogr. Sci. 9 $368-372$.

Liu C Q, Li S L, Lang Y C and Xiao H Y 2006 Using delta $15 \mathrm{~N}-$ and delta18O-values to identify nitrate sources in karst ground water, Guiyang, southwest China; Environ. Sci. Technol. 40 6928-6933.

Lumb A, Halliwell D and Sharma T 2006 Application of CCME Water Quality Index to monitor water quality: A case study of the Mackenzie River Basin, Canada; Environ. Monit. Assess. 113 411-429.

Melloul A J and Collin M 1998 A proposed index for aquifer water-quality assessment: The case of Israel's Sharon region; J. Environ. Manag. 54 131-142.
Ministry of Health of the People's Republic of China 2006 Standards for drinking water quality; GB5749-2006.

Mori N, Kanduc T, Opalicki Slabe M and Brancelj A 2015 Groundwater drift as a tracer for identifying sources of spring discharge; Ground Water 53(1) 123-132.

Parkhurst D L and Appelo C A J 2013 Description of input and examples for PHREEQC version 3-A computer program for speciation, batch-reaction, one-dimensional transport, and inverse geochemical calculations; U.S. Geological Survey, Colorado.

Petelet-Giraud E, Négrel P, Gourcy L, Schmidt C and Schirmer M 2007 Geochemical and isotopic constraints on groundwater-surface water interactions in a highly anthropized site. The Wolfen/Bitterfeld megasite (Mulde subcatchment, Germany); Environ. Pollut. 148 707-717.

Promma K, Zheng C and Asnachinda P 2006 Groundwater and surface-water interactions in a confined alluvial aquifer between two rivers: Effects of groundwater flow dynamics on high iron anomaly; Hydrogeol. J. 15 495513.

Rodgers P, Soulsby C, Petry J, Malcolm I, Gibbins C and Dunn S 2004 Groundwater-surface-water interactions in a braided river: A tracer-based assessment; Hydrol. Process. 18 1315-1332.

Senthilkumar M and Elango L 2013 Geochemical processes controlling the groundwater quality in lower Palar river basin, southern India; J. Earth Syst. Sci. 122 419-432.

Senthilkumar M, Arumugam R, Gnanasundar D, Thambi D S C and Kumar E S 2015 Effects of geological structures on groundwater flow and quality in hardrock regions of northern Tirunelveli district, southern India; J. Earth Syst. Sci. 124 405-418.

Smith R L, Bohlke J K, Song B and Tobias C 2015 Role of anaerobic ammonium oxidation (anammox) in nitrogen removal from a freshwater aquifer; Environ. Sci. Technol. 49 12,169-12,177.

Štambuk-Giljanović N 1999 Water quality evaluation by index in Dalmatia; Water Res. 33 3423-3440.

Sun S, Zhou Z, Xiao W and Wang H 2014 Impact analysis on water quality of the Second Songhua river based on mathematical model; J. Clean Energy Technol. 2(3) $240-243$.

Thyne G, Güler C and Poeter E 2004 Sequential analysis of hydrochemical data for watershed characterization; Ground Water 42 711-723.

Winter T C, Harvey J W, Franke O L and Alley W M 1998 Ground Water and Surface Water: A Single Resource; Diane Publ. Co, Denver, Colorado.

Woessner W W 2000 Stream and fluvial plain ground water interactions: Rescaling hydrogeologic thought; Ground Water 38 423-429.

World Health Organization 2011 Guidelines for drinkingwater quality; 4th edn, World Health Organization.

Yu S, Shang J, Zhao J and Guo H 2003 Factor analysis and dynamics of water quality of the songhua river, northeast china; Water Air Soil Pollut. 144 159-169. 